\title{
Riesgo de trastornos alimentarios y perfil antropométricos en modelos profesionales de M éxico
}

\author{
Risk of eating attitudes and anthropometric profile \\ among professional fashion models of M exico
}

\begin{abstract}
O bjective: The aim of this study was to compare the risk of Eating Disorders Behaviour (EDB), and its anthropometric profile, physical activity and alimentary intake between Mexican fashion models (FM) and control women M ethods: We included 50 $\mathrm{FM}$ and 50 control women, of the same social group, all over 18 years old, from Guadalajara, Mexico, matched by age. We evaluated the risk of EDB with the Eating Attitudes Test (EAT26); the anthropometric measures were taken according to the criteria of the International Society for the Advancement of Kinanthropometry (ISAK), 24-hour recall to estimate energy intake and physical activities. Results: The risk prevalence of ED B was $10 \%$ for both groups. The mean and standard deviation of the percentage of body fat in FM was $22,4 \pm 2$, lower than in the controls $(27,8 \pm 4, p<0.001)$. There were no differences in anthropometric measurements in women with and without risk of $E D B$, except in the weight (FM without risk of EDB $56,3 \pm 3$ $\mathrm{kg}$ and $59,9 \pm 3 \mathrm{~kg}$ with risk of EDB $(p<0.02)$. Caloric intake in women with risk of EDB reduced was 1094 $208 \mathrm{kcal}$ in FM versus $1269 \pm 435 \mathrm{kcal}$ in control woman. Conclusion: The anthropometric measurements, alimentary intake and previous history of eating disorders, suggests that FM of Mexico are a vulnerable population for eating disorder.

Key words: anorexia nervosa, bulimia nervosa, fashion models, body mass index; caloric intake|.
\end{abstract}

\section{INTRODUCTION}

The preference for thinness and altered body perception have caused an increase of psychiatric illnesses named Eating Disorders (ED), such as anorexia nervosa, bulimia nervosa, eating disorders not otherwise specified and binge eating disorder (1).

The diagnosis of ED, for anorexia nervosa and bulimia nervosa require an individual evaluation based on the Diagnostic and Statistical Manual of Mental Disorders (DSM-V) criteria (1). Also there are assessments that allow screening of the population at risk of ED (EDR), and these can indicate abnormal eating attitudes and behavior being the Eating Attitude Test (EAT-26) one of the most common tools used for EDR identification (2).

EDR has been performed especially in teenage women with a prevalence fluctuating around $14.5 \%$ and $24.6 \%(3,4)$. The risk has been related with the development of a slender body as a beauty standard (5); set by the mass media, leading
Blanca Miriam Torres-Mendoza $(1,2,3)$

Perla Karina M ercado-Barajas (3)

Patricia Sánchez-Rivera (3)

Elizabeth Hernández-González (3)

Martha Escoto-Delgadillo (4)

Eduardo Vázquez-Valls (5)

(1) Departamento de Clínicas M édicas, Centro U niversitario de Ciencias de la Salud,

Universidad de Guadalajara, Guadalajara, Jalisco, M éxico. (2) División de Neurociencias, Centro de Investigación Biomédica de O ccidente Centro Médico N acional de O ccidente, Instituto M exicano del Seguro Social, Guadalajara, Jalisco, México

(3) Programa de Trastornos de la Conducta Alimentaria Departamento de Ciencias de la Salud, U niversidad del Valle de Atemajac, Zapopan, Jalisco, México.

(4) Centro U niversitario de Ciencias Biológicas y Agropecuarias, U niversidad de Guadalajara, Guadalajara, Jalisco, México

(5) Dirección de Educación y de Investigación, U.M.A.E Hospital de Especialidades, Centro M édico N acional de O ccidente, Instituto M exicano del Seguro Social, Guadalajara, Jalisco, M éxico.

Corresponding author Blanca M iriam Torres-M endoza, PhD, M Sc Departamento de Clínicas M édicas, Centro Universitario de Ciencias de la Salud Universidad de Guadalajara, H ospital 308, El Retiro, CP 44280 Guadalajara, Jalisco, M éxico Phone: +52 (33)36170060 ext 31950 E-mail: bltorres1@hotmail.com

Este trabajo fue recibido el 12 de Agosto de 2015 y aceptado para ser publicado el 20 de Octubre de 2015.

to potential damage to physical and emotional health $(6,7)$. Women devoted to fashion modeling as a professional activity, present a greater EDR due the strict slenderness requirement for that activity (8).

European studies suggest female fashion models (FM) have more vulnerability in developing thinness and to have a slimmer body when being compared to women of their age who are not related to modelling (8). It is possible that this influence is not as high in developing countries like Mexico. The aim is to compare the EDR behaviour, and its anthropometric profile, physical activity and alimentary intake between Mexican FM and women control.

\section{SUBJECTS AND METHODS}

Participants and design

To compare means it was used the formula $n=[2(\mathrm{Z} \alpha+$ $Z \beta) 2 * \$ 2] / \delta 2$ and has been used to calculate the sample size, it was performed for the variable percentage of body fat, 
with the following criteria: difference of $2 \%$, variance 12.25 , power $80 \%$ and confidence interval of $95 \%$. The sample size obtained was 50 per group.

Fifty professional FM were selected to enter this study, each having at least one year of professional experience with a modeling agency. Also, fifty women were included as controls. Both groups were over 18 years old, not pregnant or in lactation, being residents of Guadalajara, Mexico.

\section{Procedure}

Five professional runway model agencies were invited to participate. Women from the control group were selected for the same social status of the models, and matched by age. Females from both groups signed an informed consent. This study was approved by Universidad del Valle de Atemajac's Research and Bioethics Committee and complied with Mexican Research Regulations and the Declaration of Helsinki.

General data was obtained during face to face interviews and daily caloric intake was obtained by the 24 hour recall questionnaire. The EAT-26 was obtained by self-report. Anthropometric data was recorded by trained personal.

\section{General Data and EAT}

The variables recorded were age, time in fashion modeling, desired and ideal weight, minimum and maximum weight since their 18th birthday; and if there has been previous ED treatment. EAT-26 instrument evaluates attitudes and behavior associated with ED (2).

\section{Anthropometric evaluation}

The anthropometric measurements were performed by two nutritionists according to the International Society for the Advancement of Kinanthropometry (ISAK, 2000) standards (9). The skinfolds were recorded in the morning as follows: bicipital, tricipital, suprailiac and subscapular; and were measured with a Harpenden ${ }^{\circledR}$ skinfold Caliper, with 99.9\% accuracy (John Bull, British Indicators Ltd, West Sussex, UK). The sum of the skinfolds was used to obtain the estimated body density (Siri, 1961) (10). The fat mass was calculated with the Durning \& Womersley formula (11).

The waist and hip circumferences were measured to determine the type of fat distribution, considering a ratio $\geq$ 0,84 as an android pattern, $\leq 0.70$ as gynecoid and between 0,71 and 0,83 as normal (12).

The body mass index (BMI) was obtained; the measurements were made with a scale (Tanita UM-061) and stadiometer (Seca). Their nutritional status was classified according to the World Health Organization as: severe thinness $<16,00$ $\mathrm{kg} / \mathrm{m} 2$, moderate thinness $16,1-16,99 \mathrm{~kg} / \mathrm{m} 2$, mild thinness $17,1-18,49 \mathrm{~kg} / \mathrm{m} 2$ and normal 18,5-24,9 kg/m2 (13).

\section{Alimentary intake}

We obtained the intake of kcal per day and the percentage of proteins, lipids and carbohydrates by 24-hour recall from the previous day of the recording, using the Mexican System of Food Equivalents (14). FM only accepted an interview to assess the alimentary intake due to their busy schedules of work. Resting energy expenditure (REE) was calculated (15).

\section{Physical activity}

The studied population self-reported if they were sedentary or if they practiced recreational, scholar or competitive physical activity.
Statistical analyses

The data was analysed using the Statistical Package for Social Sciences (SPSS version 22), being described in frequencies, percentages, mean and standard deviation (sd) and compared with chi-square or Fisher exact tests. We applied the Levene test to identify homogeneity of quantitative variables; these variables showed no homogeneity $(p<0.05)$, then these were compared with the non-parametric Wilcoxon test. The reliability coefficients of the EAT-26 test were determined by the Cronbach's alpha coefficient.

\section{RESULTS}

One hundred women were included, $50 \mathrm{FM}$ and 50 controls, on average were $21,9 \pm 3,4$ years of age.

The FM had greater height, with an average of $174,4 \pm 3,4$ $\mathrm{cm}$ compared with $163,8 \pm 6,1 \mathrm{~cm}$ in the control group ( $p$ $<0.0001)$; no differences were found in weight. The control showed higher skinfolds versus $F M$, both EDR and non-EDR, as follows: BSF 5,2 $\pm 1,2 \mathrm{~mm}$ and 5,5 $\pm 0,3 \mathrm{~mm}$ versus $7,6 \pm 3,6 \mathrm{~mm}$ and $6,4 \pm 1,5 \mathrm{~mm}(\mathrm{p}<0.001) ; \mathrm{TSF} 11,4 \pm 2,8 \mathrm{~mm}$ and $12,5 \pm 1,1$ $\mathrm{mm}$ versus $16,6 \pm 4,9 \mathrm{~mm}$ and $17,8 \pm 3,3 \mathrm{~mm}(\mathrm{p}<0.001)$; SISF $11,4 \pm 3,2 \mathrm{~mm}$ and $11,3 \pm 3,2$ versus $17,0 \pm 7,4$ and 15,5 $\pm 5,7$ ( $<0.001)$; SSSF $10,1 \pm 2,5 \mathrm{~mm}$ and 9,9 $\pm 2,4$ versus $15,1 \pm 5,3$ and $12,5 \pm 3,9 \mathrm{~mm}(\mathrm{p}<0.001)$ as well as AC 24,2 $\pm 1,3$ and 24, 9 $\pm 0,7$ versus $25,9 \pm 2,5 \mathrm{~cm}$ and $26,2 \pm 1,6 \mathrm{~cm}(p<0.001)$. The same trend was shown in waist circumference $64,2 \pm 2,5$ and $64,1 \pm 3,7$ versus $67,8 \pm 5,5$ and $65,6 \pm 4,2(p<0.001)$ and in hip with $92,7 \pm 2,7$ and $94,3 \pm 2,9$ versus $94,4 \pm 5,8$ and $97,8 \pm 2,5$ $(p<0.04)$ both in controls versus FM for EDR and non- EDR respectively.

The mean percentage of fat mass in women with EDR and non-EDR were $22,3 \pm 2,6$ and $22,9 \pm 1,2$ in FM lower than controls $28,0 \pm 5,0$ and $26,8 \pm 3,5$ ( $p<0.001$ ).

The WHR was higher in non-EDR control women $0,72 \pm 0,03$ compared with EDR 0,67 $\pm 0,05$; but in FM were

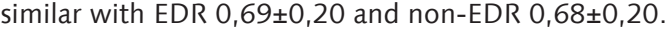

Weight greater reached (weight + ) and weight low reached (weight -) showed no difference between FM and controls. The age, anthropometric measurements, higher and lower weight, achieved during adulthood, and desired weight in the women studied is shown in table 1.

The body fat distribution was of gynecoid pattern in FM $46(92 \%)$, in contrast with $28(56 \%)$ of the control group ( $p$ $<0,0001)$. The rest presented a normal distribution and no one presented an android type. Nine out of ten women with EDR presented a gynecoid pattern.

The EAT-26 showed an internal consistency with a Cronbach's alpha of 0,846 and 0,860 for FM and controls respectively. The EAT-26 score, the macronutrients ratios, caloric intake and total energy expenditure (REE) showed no difference between the control and the FM (table 2).

However, calorie intake was lower in FM with risk of EDR with $1094,2 \pm 208,3 \mathrm{kcal} / \mathrm{d}$ than in controls $1269,8 \pm 435,0$ $\mathrm{kcal} / \mathrm{d}(\mathrm{p}<0.03)$.

Of the control group, only $8 \%$ declared to feel guilty after eating. At least three FM accepted a previous treatment for ED.

The EDR frequency was similar in the FM $(n=5)$ and women control $(n=5)$, representing a prevalence of $10 \%$; difference in educational level were found with 8 control women with postgraduate education and FM group the frequency of women in high school was higher with 15 $(p<0.005)$, physical activity and ED treatments showed no differences. 
Moreover, 25 (50\%) of the FM presented thinnes, assessed by the BMI compared to $7(14 \%)$ of the controls $(p<0.001)$. (table 3).

\section{DISCUSSION}

EDR in Mexican FM and control women were similar (10\%), that data showed almost three rate points above the percentage described in the most recent survey in a similar population in Sardina Italy, where Preti et al. emphasizes evaluation by face to face interviews in order to minimize bias (8). In European FM showed a slightly higher frequency in comparison to our study (12.7\%). However, they had a total response rate of $74 \%$, and the control group was unmatched (16). In the Netherlands, no EDR among FM and modeling students was found, but that study had a very high bias by the low response rate of $16 \%$ (17).
EDR in Mexico has not been reported in FM; but in teenagers younger than 18 years, finding out it was $16.1 \%$ and $25 \%$ (4). Peer pressure, population ideal of slenderness, and the feeling of being displeased with corporal image, are components that promote the presence of $\operatorname{ED}(18,19)$. The difference with this survey is that older women, FM and the risk instrument used by Unikel et al. is different to EAT-26 (18).

$\mathrm{BMI}$ and anthropometric measures

The average BMI fluctuates between 17.7 and $17.9 \mathrm{~kg} /$ $\mathrm{m} 2$ in the population of professional FM in Italy and other different countries $(8,16)$; below the BMI found in Mexican $F M$, this can be an indirect indication of the demand for thinness by some agencies in Mexico, were models can present a higher corporal leanness, compared with the requirements of other countries.

\section{TABLE 1}

Date anthropometrics by eating disorder risk in fashion model or women Mexican

\begin{tabular}{|c|c|c|c|c|c|c|c|}
\hline & \multicolumn{2}{|c|}{ Fashion model } & \multicolumn{4}{|c|}{ Control } & \multirow{2}{*}{$\begin{array}{c}\mathrm{p}< \\
\text { FM versus } \\
\text { control }\end{array}$} \\
\hline & $\begin{array}{c}\text { Non- EDR } \\
\text { Mean (sd) } \\
n=45\end{array}$ & $\begin{array}{c}\text { EDR } \\
\text { Mean (sd) } \\
n=5\end{array}$ & $\mathrm{p}<$ & $\begin{array}{c}\text { Non- EDR } \\
\text { Mean (sd) } \\
n=45\end{array}$ & $\begin{array}{c}\text { EDR } \\
\text { Mean (sd) } \\
\mathrm{n}=5\end{array}$ & $\mathrm{p}<$ & \\
\hline Age (yr) & $22,1(3,4)$ & $20,4(3,8)$ & 0,307 & $22,1(3,5)$ & $20,4(2,5)$ & 0,307 & 1,000 \\
\hline Weight (kg) & $56,3(3,1)$ & $59,9(3,6)$ & 0,02 & $57,0(7,8)$ & $59,2(2,7)$ & 0,528 & 0,638 \\
\hline Height $(\mathrm{cm})$ & $174,2(3,4)$ & $176,3(4,0)$ & 0,195 & $163,8(6,5)$ & $163,8(3,4)$ & 0,992 & 0,001 \\
\hline $\mathrm{BMI}(\mathrm{kg} / \mathrm{m} 2)$ & $18,6(1,0)$ & $19,2(0,6)$ & 0,168 & $21,2(2,5)$ & $22,1(0,9)$ & 0,452 & 0,001 \\
\hline $\mathrm{BSF}(\mathrm{mm})$ & $5,2(1,2)$ & $5,5(0,3)$ & 0,578 & $7,6(3,6)$ & $6,4(1,5)$ & 0,466 & 0,001 \\
\hline TSF (mm) & $11,4(2,8)$ & $12,5(1,1)$ & 0,391 & $16,6(4,9)$ & $17,8(3,3)$ & 0,600 & 0,001 \\
\hline SISF (mm) & $11,4(3,2)$ & $11,3(3,2)$ & 0,939 & $17,0(7,4)$ & $15,5(5,7)$ & 0,672 & 0,001 \\
\hline SSSF (mm) & $10,1(2,5)$ & $9,9(2,4)$ & 0,904 & $15,1(5,3)$ & $12,5(3,9)$ & 0,299 & 0,001 \\
\hline$A C(\mathrm{~cm})$ & $24,2(1,3)$ & $24,9(0,7)$ & 0,304 & $25,9(2,5)$ & $26,2(1,6)$ & 0,809 & 0,001 \\
\hline Waist $(\mathrm{cm})$ & $64,2(2,5)$ & $64,1(3,7)$ & 0,928 & $67,8(5,5)$ & $65,6(4,2)$ & 0,398 & 0,001 \\
\hline Hip (cm) & $92,7(2,7)$ & $94,3(2,9)$ & 0,212 & $94,4(5,8)$ & $97,8(2,5)$ & 0,203 & 0,041 \\
\hline Fat $(\%)$ & $22,3(2,6)$ & $22,9(1,2)$ & 0,609 & $28,0(5,0)$ & $26,8(3,5)$ & 0,610 & 0,001 \\
\hline WHR & $0,69(0,20)$ & $0,68(0,20)$ & 0,20 & $0,72(0,03)$ & $0,67(0,05)$ & 0,008 & 0,001 \\
\hline Weight - (kg) & $52,7(3,1)$ & $56,6(5,2)$ & 0,09 & $52,6(7,1)$ & $50,8(6,6)$ & 0,974 & 0,500 \\
\hline Weight + (kg) & $60,3(5,1)$ & $63,2(4,0)$ & 0,224 & $60,0(8,9)$ & $60,2(3,8)$ & 0,956 & 0,606 \\
\hline Desired weight $(\mathrm{kg})$ & $55,5(2,5)$ & $56,4(2,7)$ & 0,456 & $54,1(6,0)$ & $54,2(2,6)$ & 0,971 & 0,007 \\
\hline
\end{tabular}

Arm circumferences (AC), biceps skinfolds (BSF), body mass index (BMI), fat mass percentage (Fat), hip circumference (Hip), fashion model (FM), suprailiac skinfold (SISF), subscapular skinfold (SSSF), tricipital skinfolds (TSF), waist circumference (WC), waist/hip rate (WHR), weight low reached (weight - ), weight greater reached (weight + ). $n=50$ women/group

TABLE 2

Intake of macronutriments and score of EDR in women by risk eating disorder

\begin{tabular}{|c|c|c|c|c|c|c|c|}
\hline & \multicolumn{2}{|c|}{ Fashion model } & \multicolumn{4}{|c|}{ Control } & \multirow{2}{*}{$\begin{array}{c}\mathrm{p}< \\
\text { FM versus } \\
\text { control }\end{array}$} \\
\hline & $\begin{array}{c}\text { Non-EDR } \\
\text { Mean (sd) } \\
n=45\end{array}$ & $\begin{array}{c}\text { EDR } \\
\text { Mean (sd) } \\
n=5\end{array}$ & $\mathrm{p}<$ & $\begin{array}{c}\text { Non-EDR } \\
\text { Mean (sd) } \\
n=45\end{array}$ & $\begin{array}{c}\text { EDR } \\
\text { Mean (sd) } \\
n=5\end{array}$ & $\mathrm{p}<$ & \\
\hline Fat (\%) & $22,3(2,6)$ & $22,9(1,2)$ & 0,609 & $28,0(5)$, & $26,8(3,5)$ & 0,610 & 0,001 \\
\hline Carbohydrate (\%) & $51,9(10,6)$ & $49,0(4,0)$ & 0,547 & $54,2(8,6)$ & $56,0(6,3)$ & 0,647 & 0,147 \\
\hline Protein (\%) & $21,0(5,4)$ & $25,0(3,5)$ & 0,115 & $19,7(3,7)$ & $18,8(5,0)$ & 0,619 & 0,059 \\
\hline Lipid (\%) & $27,1(7,7)$ & $26,0(6,3)$ & 0,768 & $26,1(6,6)$ & $25,2(3,0)$ & 0,764 & 0,502 \\
\hline Calories (kcal/d) & $1532,4(442,9)$ & $1094,2(208,3)$ & 0,03 & $1715,1(568,0)$ & $1269,8(435,0)$ & 0,097 & 0,078 \\
\hline $\operatorname{REE}(\mathrm{kcal} / \mathrm{d})$ & $1760,5(84,3)$ & $1866,4(98,9)$ & 0,02 & $1758,3(159,1)$ & $1826,8(79,8)$ & 0,160 & 0,488 \\
\hline EDR (EAT26 score) & $5,4(4,5)$ & $30,0(6,9)$ & 0,000 & $5,9(4,3)$ & $28,8(14,0)$ & 0,001 & 0,858 \\
\hline
\end{tabular}

Eating disorders risk (EDR); Eating Attitude Test (EAT-26); total energy expenditure (REE), n = 50 women/group 
However half of the FM $(n=25)$ and $14 \%(n=7)$ of controls showed a BMI below $18.49 \mathrm{~kg} / \mathrm{m} 2$, which is the cut-off value for malnutrition similar to that reported in Italy (8). The body fat percentage in girls with anorexia nervosa is lower than those found in women without anorexia nervosa. (20) This survey, its percentage was higher in the control women than in the FM. Differences were found in fat mass percentages which were higher in controls, suggesting a relationship with the discontent with their body shape $(21,22)$.

The waist and hip circumferences are similar in both groups; even so we emphasize the WHR, because its tendency to decrease in FM. The body distribution types classified FM with a gynecoid pattern, as has been reported in other studies (23), we did not found relationship with a high score of EDR and circumferences (26).

However, the gynecoid pattern is characterized by a hip wider than the waist, and less abdominal fat presented by almost half of the control; an android type is related with a narrower hip. Women with low WHR tend to be more feminine and attractive (24). There is a tendency to present an androgynous body shape, the latter associated to a very low weight; like to the tubular shape, as the top models presenting (24).

In regard to the highest and lowest weights referred throughout their lives, the category was set out to evaluate the stability of the anthropometric variants, this item was not different with the study group, and however the desired weight was lower among the control group than in the models, possibly because the models present moderate slenderness.

The caloric intake among women with ED is lower than their requirements and it is surprising that controls also present a reduced alimentary intake, but the FM at EDR had an alimentary intake almost a third lower compared to the models without risk.

The caloric restriction and physical activity have been described as an influence in the anthropometric measures, but no differences were found in the anthropometric measurements within the FM and the control groups; however it must be emphasized that the FM mean height was higher, putting corporal measures in slight to moderate slenderness; similar to that reported in other studies (25). Our consideration must evaluate the lifestyle and diet types due restrictive measures of alimentary intake.

The intake in the 24 hour previous to the survey does not represent several days intake; being a bias their refusal to answer questions regarding the amount work excess in the runaways. Nevertheless the results suggest that the proportion of macronutrients is higher in the lipid intake in all women with or without EDR as opposed to the proposal of Bas and Kizitan (26), which could be confirmed with further studies.

This study reflects an EDR behavior similar between FM and controls. Nevertheless the anthropometric measurements are in mild to moderate slenderness in FM, with reduced nutritional intake, compared to their requirements. The history of treatment for ED in three FM reaffirms that is a vulnerable population requiring further studies focusing on restrictive eating behaviors, and do not rule out educational prevention of $E D$ in $F M$.

Acknowledgements: Research conducted and recorded in Programa de Trastornos de la Conducta Alimentaria, Licenciatura en Nutrición, Departamento de Ciencias de la Salud, Universidad del Valle de Atemajac, Avenida Tepeyac 4000, Zapopan, Jalisco, México.

Authors thank to Mayapur Hernández Torres for proofreading and editing in translation.

\section{RESUMEN}

Objetivo: Comparar el riesgo de trastornos de la conducta alimentaria (TCA), perfil antropométrico, actividad física e ingesta alimentaria entre las mujeres mexicanas dedicadas al modelaje profesional (MP) con mujeres control. Métodos: Se incluyeron 50 MP y 50 mujeres controles, del mismo grupo social, mayores de 18 años, de Guadalajara, México, pareadas por edad. Se evaluó el riesgo de TCA con el test de Trastornos de Actitudes Alimentarias (EAT-26), se tomaron las medidas antropométricas de acuerdo a los criterios de la International

TABLE 3

Frequency of EDR, educational level, physical activity, history of ED treatments and Body Mass Index

\begin{tabular}{|c|c|c|c|c|}
\hline & & $\begin{array}{c}\mathrm{FM} \\
\mathrm{n}=50\end{array}$ & $\begin{array}{c}\text { Control } \\
n=50\end{array}$ & $\mathrm{Ji2} P$ \\
\hline \multirow[t]{2}{*}{ EDR } & No & 45 & 45 & ns \\
\hline & Yes & 5 & 5 & \\
\hline \multirow[t]{4}{*}{ Educational level } & Secondary & 0 & 1 & 0,005 \\
\hline & High school & 15 & 6 & \\
\hline & University & 35 & 35 & \\
\hline & Posgraduate & 0 & 8 & \\
\hline \multirow[t]{4}{*}{ Physical activity } & Sedentary & 25 & 27 & ns \\
\hline & Recreative & 25 & 19 & \\
\hline & Scholar & 0 & 1 & \\
\hline & Competitive & 0 & 3 & \\
\hline \multirow[t]{2}{*}{ History of ED treatments } & No & 47 & 48 & ns \\
\hline & Yes & 3 & 1 & \\
\hline \multirow[t]{4}{*}{ Body Mass Index } & Normal & 25 & 43 & 0.001 \\
\hline & Mild thinnes & 22 & 6 & \\
\hline & Moderate thinnes & 3 & 0 & \\
\hline & Severe thinnes & 0 & 1 & \\
\hline
\end{tabular}


Society for the Advancement of Kinanthropometry (ISAK). Se estimó el consumo de energía utilizando el recordatorio de 24 horas y se registró la práctica de actividades físicas. Resultados: La prevalencia de riesgo de TCA fue 10\% para ambos grupos. La media y desviación estándar del porcentaje de grasa corporal en las MP fue $22,4 \pm 2,5$ menor al de las controles $(27,8 \pm 4,9)$ $(p<0.001)$. No hubo diferencias en la medidas antropométricas en las mujeres con y sin riesgo de TCA, excepto en el peso de las MP de $56,3 \pm 3,1 \mathrm{~kg}$ sin riesgo de TCA y 59,9 93,6 en las con riesgo de TCA $(p<0.02)$. La ingesta alimentaria se encontró reducida en las mujeres con riesgo de TCA con respecto a las sin riesgo, con $1094,2 \pm 208,3 \mathrm{kcal}$ versus $1269,8 \pm 435,0$ kcal en las MP y controles respectivamente. Conclusión: Las medidas antropométricas, la ingesta alimentaria y la historia previa de trastornos de la alimentación, sugiere que la MP de México es una población vulnerable para trastornos de la alimentación.

Palabras clave: anorexia nerviosa, bulimia nerviosa, modelos profesionales, índice de masa corporal; ingesta calórica.

\section{REFERENCES}

1. American Psychiatric Association. Diagnostic and Statistical Manual of Mental Disorders, 5th ed. Arlington,VA: American Psychiatric Association 2013.

2. Garner DM, Olmsted MP, Bohr Y, et al. The eating attitudes test: psychometric features and clinical correlates. Psychol Med. 1982; 12: 871-8.

3. Haines J, Ziyadeh NJ, Franko DL, McDonald J, Mond JM, Austin SB. Screening high school students for eating disorders: validity of brief behavioral and attitudinal measures. J Sch Health 2011; 81: 530-5.

4. Toro J, Gomez-Peresmitré G, Sentis J, et al. Eating disorders and body image in Spanish and Mexican female adolescents. Soc Psychiatry Psychiatr Epidemiol 2006; 41: 556-65.

5. Austin SB, Ziyadeh NJ, Forman S, et al. Screening high school students for eating disorders: results of a national initiative. Prev Chronic Dis. 2008; 5: A114-535.

6. Turner $S L$, Hamilton $H$, Jacobs $M$, et al. The influence of fashion magazines on the body image satisfaction of college women: an exploratory analysis. Adolescence 1997; 32: 603-14.

7. Chow J. Adolescents' perceptions of popular teen magazines. J Adv Nurs. 2004; 48:132-9.

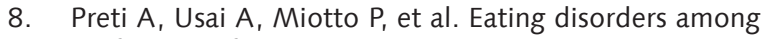
professional fashion models. Psychiatry Res 2008; 159: 86-94.

9. Norton K, Whittingham N, Carter L, Kerr D, Gore C, Marfell-Jones $M$. Measurement techniques in anthropometry. In: Norton, K. and Olds, T. (eds). Anthropometrica. Syndey: UNSW/ Press. 1996.

10. Siri WE. Body composition from fluid spaces and density: analysis of methods. In: Brozeck J, Henschel A eds. Techniques for measuring body composition. Washington, DC: National Academy of Sciences. 1961.
11. Durnin JV, Womersley J. Body fat assessed from total body density and its estimation from skinfold thickness: measurements on 481 men and women aged from 16 to 72 years. Br J Nutr. 1974; 32: 77-97.

12. Pérez-Lizaur AB, Marván-Laborde L. Manual de dietas normales y terapéuticas: los alimentos en la salud y la enfermedad. (6a. ed). México: Prensa Médica Mexicana. 2007.

13. World Health Organization. Obesity: BMI classification. Available at http://apps.who.int/bmi/index. jsp?introPage=intro_3.html. Accessed August 2, 2014.

14. Marván-Laborde L, Pérez-Lizur AB, Palacios-González B. Sistema mexicano de alimentos equivalentes. $2^{\mathrm{a}}$ ed. Ciudad de México: Fomento de Nutrición y Salud AC. 2006.

15. Harris JA, Benedict JA. A biometric study of basal metabolism in man. Carnegie Institute of Washington, DC Publication no. 270. 1919.

16. Santonastaso $P$, Mondini S, Favaro A. Are fashion models a group at risk for eating disorders and substance abuse? Psychother Psychosom. 2002; 71: 168-72.

17. van Hanswijck de Jonge $P$, van Furth EF. Eating disorders in models: fiction or fact?. Eur Eat Disorders Rev. 1999; 7:235-8.

18. Unikel C, Aguilar J, Gómez-Peresmitré G. Predictors of eating behaviors in a sample of Mexican women. Eat Weight Disord. 2005; 10: 33-9.

19. Andrade FC, Raffaelli $M$, Teran-Garcia $M$, Jerman JA, Garcia CA. Up Amigos 2009 Study Group Weight status misperception among Mexican young adults. Body Image 2012; 9; 184-8.

20. El Ghoch $M$, Calugi S, Lamburghini S, Dalle Grave R. Anorexia Nervosa and Body Fat Distribution: A Systematic Review. Nutrients. 2014; 6: 3895-912.

21. Davis $C$, Durnin JV, Dionne $M$, et al. The influence of body fat content and bone diameter measurements on body dissatisfaction in adult women. Int J Eat Disord. 1994; 15: 257-63.

22. Zanetti $T$, Santonastaso $P$, Sgaravatti $E$, Degortes D, Favaro A. Clinical and temperamental correlates of body image disturbance in eating disorders. European Eating Dis Rev. 2013; 21; 32-7.

23. Yannakoulia $M$, Matalas $A L$, Yiannakouris $N$, et al. Disordered eating attitudes: an emerging health problem among Mediterranean adolescents. Eat Weight Disord. 2004; 9: 126-33.

24. Singh D. Universal allure of the hourglass figure: an evolutionary theory of female physical attractiveness. Clin Plast Surg. 2006; 33: 359-70.

25. Vancampfort D, Vanderlinden J, Stubbs B, et al. Physical Activity Correlates in Persons with Binge Eating Disorder: A Systematic Review. European Eating Dis Rev. 2013:22:1-8.

26. Baș $M$, Kiziltan $G$. Relations among weight control behaviors and eating attitudes, social physique anxiety, and fruit and vegetable consumption in Turkish adolescents. Adolescence 2007; 42: 167-78. 